\title{
Intercultural Education in Poland: Current Problems and Research Orientations
}

\begin{abstract}
The study presents an assessment of the achievements and problems of intercultural pedagogy as an important educational (sub)discipline, which has been developing intensively in Poland - particularly since the 1990s. Against the background of a crisis of multicultural education, a new suggestion was presented aimed at overcoming its drawbacks in the form of the theoretical assumptions and practical solutions of intercultural education. However, understanding and accepting intercultural education depends on many factors - e.g., historical experiences, the developmental level of societies and the socio-political system. This necessitates presenting the essence of intercultural education as well as formulating its message both in Poland and worldwide.
\end{abstract}

Keywords:

pedagogy, intercultural pedagogy, multicultural education, intercultural education, scientific schools in Poland

\section{INTRODUCTION}

For almost last three decades, the studies into intercultural education have become a part of the Polish social discourse concerning the issues of multiculturalism, the feeling of (national, civil, ethnic, religious, cultural) identity, or the relationships between people of different nationalities and cultures. Social experiences and daily practice confirm the constant need for opening to other communities and their cultures, which means the need for implementing reliable intercultural

Institute of Education, Faculty of Ethnology and Educational Science, University of Silesia in Katowice, Poland, E-MAIL: eom1@wp.pl. 
education. On the other hand, a return to multicultural education can be observed - minority groups again focus on the lasting of their own culture and researchers, with growing frequency, focus on a selected culture or minority group. In this way, the field of studies and educational practice has been limited and significantly impoverished (Lewowicki, 2006, p. 268).

Contemporary societies search for solutions to many problems resulting, among other things, from the rapid development of the industrial-informational civilization. The size and nature of this phenomenon is shown by many researchers, who draw attention to the so called paradoxical socialization (Sztompka, 2012, pp. 464-472) - people are forced to shape their own life without control over its determinants. This is related to the disintegration of the society into many fields of activity which do not constitute any unity. The lack of moving around within a unified area of life imposes what is described as biographical coordination of diversified behavioural logics (Ostrowicka, 2013, pp. 49-73). Moreover, tradition and family education are substituted by institutions, media and individual choices. Thus, conducting reliable intercultural education makes it possible to discover and understand oneself from the perspective of noticing and evaluating Others. Its fundamental task is shaping the feeling of identity, understood as "the subject's creative effort indispensable and necessary in the multicultural world, soothing the tensions and contradictions between the constant elements, which are inherited and result from social rooting in a family and local community, the identification with significant people and groups, indigenous symbols and values, and the changeable elements, which are acquired and result from interaction and the experience of participation in culture and social structures. Such understanding of identity opens to the dialogue of cultures, in which the mutual participation in the process of opening to each other is a source of power and raises the feeling of pride because of belonging to a particular group” (Lewowicki, 2013, pp. 19-37; Nikitorowicz, 1995, 2009, p. 73).

As the approach promoted in Poland, the ideas and practice of intercultural education seem to deserve broader dissemination abroad. Partially, this has been taking place (Kyuchukov, Lewowicki, \& Ogrodzka-Mazur, 2015), yet the message of intercultural education should reach even more societies. It is important to act for this education, being fully aware that this is going to be a long process but that it will bring appropriate fruit as well.

These high expectations, requiring pedagogical optimism and the feeling of educational self-effectiveness, might raise doubt and questions among intercultural educators as for why they are addressed to them. Obviously, these are obligations of all people responsible for education and moral shaping. Yet, special addressees 
are the communities which have a clear vision of education which brings people together, opens to Others and their cultures - the communities with important experiences and achievements.

\section{THE COLLECTED EXPERIENCES OF POLISH INTERCULTURAL EDUCATION AS A PEDAGOGICAL (SUB)DISCIPLINE}

Although Polish intercultural studied have been developing only since the 1990s, they refer to a rich tradition and a well-developed network of notions concerning Polish education, elaborated by the leading scientific centres. In the second half of the 20th century, these centres initiated and provided orientation to pedagogical research. Since then, they have also disseminated the research results of their studies in Poland and worldwide, contributing to the interdisciplinary view on this scientific discipline.

The theoretical studies and practical research into culturally diversified environments have been initiated and continued by three leading schools of scientific thought, conducting the studies in the Polish-Lithuanian-Belarusian-Ukrainian borderland (Jerzy Nikitorowicz's team from the University of Białystok), the Polish-Czech borderland in Cieszyn Silesia (Tadeusz Lewowicki's team from the University of Silesia) and the Polish-German-Czech-Slovak borderland (Zenon Jasiński’s team from the University of Opole). Intercultural studies are also conducted by university units (departments, chairs, teams) in Bydgoszcz, Gdańsk, Kraków, Lublin, Poznań, Toruń, Warsaw, and Zielona Góra.

Some universities implement didactic classes in intercultural education, students' internships concerning this education are also conducted, and there are students' research teams dealing with it. The issues of multiculturalism and intercultural education are frequently explored in B.A. and M.A. theses, as well as doctoral or habilitation dissertations.

According to Tadeusz Lewowicki, the educational experiences and scientific output of the environments exploring intercultural education allow for formulating the opinion that these accomplishments can constitute the basis for elaborating a synthesis, comprising an outline of intercultural education as a pedagogical discipline. In contrast to the earlier cases of using the term intercultural education (in the German and English language literature) (Lewowicki, Ogrodzka-Mazur, \& Szczurek-Boruta, 2000), when the name comprised some versions of multicultural education and/or only some issues typical of scientific disciplines were taken into account, in the current approach, there is space for all fundamental components of 
a scientific discipline and the determinants of its viability (Lewowicki, 2012, pp. 39-40). In the case of Polish studies, the components of intercultural education are the following:

- a clearly outlined concept of intercultural education and the understanding of pedagogy pertaining to this field of education. Promoting (in scientific works on intercultural education) such an approach to the issues consists of a coherent set of views and beliefs which indicates the reflection and activities concerning intercultural education. Referring to the definition formulated by Laurence Kohlberg and Rochelle Mayer (1993), it can be assumed that what is dealt with is the legible ideology of intercultural education;

- within educational reflection and practice, a particular relatively precise language is used - in other words, a particular notional network. As it usually occurs in humanities, some of the notions have been borrowed from other disciplines, some have been attributed the sense typical of intercultural education. What is indicated in Polish pedagogical studies on interculturalism is the need for referring to theories and concepts concerning social behaviour. "This means justified aiming at better understanding of social phenomena and processes. However, as in the field of pedagogy it is rather difficult to find satisfying theories or concepts, the representatives of this discipline reach into the output of the related disciplines. For years, sociology has been one of them. Others are social psychology or socializing (at the border of sociology) currents of psychology. More references also appear - to historical and cultural studies, studies on politics and religion. Still, it seems that what prevails are the associations with sociology, sociological interpretations of the life of multicultural communities. [...] Sociology and psychology enhance the understanding of social situations and behaviours, they suggest various explanations, interpretations" (Lewowicki, 2010, p. 303). The confrontation of different approaches - called by Tadeusz Lewowicki sociologism and pedagogism - allows to "notice important differentiations in the reasoning and acting specific to each of these approaches. In the case of intercultural education, this is a chance for noticing and understanding the originality and the primary sense of this field of education. In contrast to the typical (of other disciplines) view on the multitude of cultures existing »next to « each other, what is significant in intercultural education is the existence of cultures »together « - with mutual recognition, impact, and acceptance of other cultural influences. This is also a view, more and more close to sociology, on the multidimensional identity of the modern human (who keeps the bonds with the »little homeland«, region, state, society, Europe). This means admitting 
that, apart from the "given identity«, there can be and there is the »chosen identity«. These and many other issues should be subjected to a multisided (also pedagogical and sociological) observation [...] Sociology, even without the undertakings aimed at social changes, provides an opportunity of »monitoring « educational activity, controlling its outcomes, and social perception. This increases the chances, to say it in the simplest way, for rational educational influence. The advantages of some interrelations with sociology are not one-sided. Intercultural education is a field for new observations and sociological analyses. This may be beneficial for both sociology and pedagogy, intercultural education” (Lewowicki, 2010, pp. 307-308);

- the area of interests, research fields and subjects have been also specified rather clearly, which is reflected in many scientific studies. The interdisciplinary character of intercultural education should be emphasized - the results of research activity of the major schools are presented in the publications issued in the scientific journal "Edukacja Międzykulturowa" [Intercultural Education] (indexed on the point scoring list of the Ministry of Science and Education) and in the publishing series Edukacja Międzykulturowa [Intercultural Education], so far comprising over 150 volumes;

- referring to some related humanistic disciplines, a wide range of methods, techniques and research tools are used in both quantitative and qualitative studies, rich research results have been also collected;

- the research and structural undertakings follow the guidelines of many theories present in social sciences. Polish intercultural education has its own interesting theoretical suggestions, which is not frequent in pedagogy. Tadeusz Lewowicki's Theory of Identity Behaviours can serve as an example. It provides a new perspective in the search for regularities which determine the feeling of identity in the multicultural environment. The theory promotes a comprehensive but at the same time comparative approach to the processes and phenomena taking place in culturally diversified environments. The author distinguishes the following fields (elements) of identity: the first - comprising historical fortunes and identification with a particular territory or social group, the second - indicated by the unlikeness of culture, language, transmission of tradition, and the knowledge of the spiritual and material wealth of a particular community, the third - associated with a specific historical genealogy and specific features of a group (groups) as well as with the stereotypes functioning within it, the fourth - concerning the economic condition and living standards of a group (groups), the fifth - associated with needs, life aims and axiological preferences, and the sixth - taking into 
account the political, ideological, social and industrial context (Lewowicki, 1995, pp. 13-26). Another important theoretical suggestion, very useful in intercultural studies, is Jerzy Nikitorowicz's Concept of multidimensional and constantly self-creating identity. It assumes an unceasing process of shaping and functioning of cultural identity in the triad: inherited identity (natural identity), acquired identity (identity of "a role”), "Ego" identity (the subjectively felt, presented and implemented identity) (Nikitorowicz, 2005, 2009, 2017). For many years, the discussed theories and concepts have been successfully applied by intercultural researchers, e.g., to design research methodology and to interpret research results (Gajdzica, Piechaczek-Ogierman, \& Hruzd-Matuszczyk, 2014; Grabowska, 2013; Kurzępa, 2007; Misiejuk, 2013; Muszyńska, 2014; Ogrodzka-Mazur, 2007; Ogrodzka-Mazur, Klajmon-Lech, \& Różańska, 2014; Różańska, 2015; Sobecki, 2007; Szczurek-Boruta, 2013; Urlińska \& Jurzysta, 2016; Wojakowski, 2007; Urban, 2014).

- the historical and contemporary output of multi- and intercultural education has some comparative approaches and the approaches which constitute the syntheses of earlier accomplishments. Intercultural pedagogy has its roots, history and the whole presentations of the earlier stages. In compliance with the good tradition of humanities, it can be said that intercultural education has the memory concerning the output of the previous generations and that it subjects this output to critical analysis;

- the condition of human resources engaged in intercultural education is worth attention. The number of researchers, scientific development, and the quality of works justify the belief that the situation of the staff contributes to a favourable prognosis for this scientific discipline. Over the last decades, many valuable publications have come into being and some new orientations have appeared in the research;

- the scientific environment dealing with intercultural education is well-organized in terms of institutions. What seems to be a huge value is the integration and tight collaboration of researchers from many academic centres and annual scientific conferences. What should be also indicated are the traditions of joint undertakings of the Social Team for Research into Borderland Culture and Education, the Team for Pedagogy of Culture and Intercultural Education of the Polish Academy of Sciences, and the Association for Supporting Intercultural Education;

- $\quad$ there are explicit and multisided interrelations between theory (theorists and researchers) and educational practice. Intercultural education fulfils the functions typical of sciences which generate practical solutions. Social needs seem 
to affect the vitality - the research scope, directions and methods - of intercultural pedagogy (Lewowicki, 2011, pp. 479-503; Lewowicki \& Suchodolska, 2011; Sobecki, 2016; Młynarczuk-Sokołowska, 2016; Łazarewicz, Winiarska, Łączyńska, \& Dziechciarz, 2016; Grzybowski, 2015; Korczyński, 2017).

\section{CURRENT PROBLEMS AND RESEARCH ORIENTATIONS}

Indicating the most important current problems and research orientations in intercultural education also means making an attempt at eliciting the fields of permanence and changeability in typical behaviour patterns in multicultural communities. These issues are worth attention due to both cognitive and practical aspects - e.g., the usefulness in shaping modern intercultural education. In this context, it seems important to carry out a critical analysis of the concepts of social, cultural and educational policy, which are formulated in Poland and many other countries and which cause that many different solutions concerning education in multicultural societies are applied.

Not only the relatively long tradition of different varieties of multicultural education but also contemporary experiences confirm that, by protecting a particular culture, this education gives rise to a lot of problems. What clearly proves the failure of many different kinds of multicultural education are the conflicts in the countries which are recognized as the models of democracy - e.g., the USA or France. The isolation of large social groups, signs of exclusion, stigmatization, poor living standards, social dissatisfaction, the feeling of discrimination are partially perpetuated by multicultural education, which functions alongside the main current of life (Lewowicki, 2017, pp. 19-35).

The analysis of numerous studies undertaking this subject matter (Biernacka, Krzysztofek, \& Sadowski, 2012; Korporowicz, 2011; Syrek, 2010) confirms the existence of two different approaches to the evaluations and consequences of the occurring changes:

- the pessimistic perspective - which assumes a crisis of multicultural education as a result of changes,

- $\quad$ the optimistic (reflective) perspective, according to which changes prove its new image, compatible with social changes and the characteristic features of the (post)modern society (Konopczyński, Theiss, \& Winiarski, 2010; Sztompka, 2016).

Applying the reflective perspective, in contrast to the radical pessimistic approach, seems to be the right direction in pedagogical research into contempo- 
rary intercultural education. The multisided approach of theorists and researchers to this issue, as well as the occurring modifications concerning its aims, tasks and functions, make it possible to notice and understand the problems and insufficiencies of multicultural education and to find the ways leading to positive solutions and appropriate activities.

\section{IN SEARCH FOR THE MODEL (NEW MODELS) OF INTERCULTURAL PEDAGOGY}

Searching for the model (models) of modern intercultural pedagogy becomes an important educational challenge and a frequent subject of expert research. Intercultural pedagogy is most often approached in these studies as:

- ars educandi, related to educational practice and comprising actually performed educational activities;

- detailed pedagogy, which is a theoretical and scientific reflection upon educational practice and which possesses its own subject matter, system of notions and methodology (Grzybowski, 2009, p. 116).

Intercultural pedagogy implemented in the conditions of cultural differentiation takes into account both the transition from ars educandi to pedagogy and the above discussed comprehension of key areas of intercultural pedagogy. Coming back to "the roots", to the paradigms of the education, to "absent discourses", it indicates a new way of re-organizing pedagogical work, which is interpreted in the categories of "the help in development, mutual help and education for development”. Thus, the intercultural perspective in pedagogy constitutes two intersecting paths. The determinant of the first is the knowledge leading from familiarization with (a new code of culture) to understanding another culture ("I know what the new code means"). The second path refers to human interactions and leads from the hypothesis of the contact with the Other to cultural training ("imagine you are the Other") (Ogrodzka-Mazur, 2013, pp. 99-110).

Due to the undertaken considerations, what becomes particularly significant is specifying cultural and cognitive contexts of intercultural early school pedagogy, which might be applied in teachers' educational activity.

\section{CULTURAL CONTEXTS}

RELATION: INDIVIDUAL - CULTURE - EDUCATION

According to Irena Wojnar (1996, p. 25), culture (viewed nowadays as "not only the heritage, the universe of creative acts of mankind, but also as the human- 
istic quality of human activity and lifestyle) becomes the basic educational authority corresponding to a new educational demand which is being born. Education is a way to make culture real - first of all 'the culture in people'. Thus, education and culture determine each other - education enlightens and culture differentiates (as 'an effect' of education), which results in an ongoing process of developing culture itself. In approaching the relation individual - culture - education, intercultural pedagogy applies the cultural orientation, which links the sphere of culture with values and personal self-development and which emphasizes the individual's liberty and self-identification (being a subject). In accordance with this:

- the individual is independent from culture, which consists in the freedom of applying an attitude to it (outside or within oneself) and to possible cultural determinism. One of the forms of applying this attitude is self-awareness. This liberty constitutes the specificity and essence of man;

- the specifically human way of existence is in fact the orientation towards values as possible elements of culture. The individual anticipates them and makes them concrete, whereas the elements attract the individual. This is not freedom towards culture but within it (Jagoszewska, 1995, p. 25).

In the suggested approach, what should be important in the education are the processes of culturation, as well as of primary and secondary socialization. On one hand, they enable rooting into culture (the assimilation of the existing cultural values) and gaining a particular place in the community. On the other hand, owing to the individual's self-fulfillment abilities, they allow individuals to "create" new, socially accepted values, in the form of cultural products, and, in this way, to create a "new” quality of the group’s or community's culture.

\section{BUILDING THE FEELING OF MULTIDIMENSIONAL CULTURAL IDENTITY}

Forming the child's feeling of multidimensional cultural identity in the individual (self-oriented) and social (outer) perspective occurs in the area of: a) "I" condition, b) the concept of oneself in the world, and c) competences concerning activity (possible contacts with the world and relations with Others). At the same time, this process is a kind of self-identification which the individual must be able both to develop along with gradual maturing and to re-define during the whole life. The individual's orientation in the surrounding cultural reality, which develops in this way, finds its representation in the system of "meanings" formulated in particular family, school, and out-of-school situations by people who are important for the individual. These meanings become a source of different values (and their possible "interpretations"), which come into being, and of developing the ability to judge the acquired knowledge and experience. Among others, the following are 
the sources of information about oneself, which might become the foundation of shaping the feeling of identity of the individual in natural and constructed educational situations:

- observing one's own behaviour and its consequences,

- observing other people's behaviour and comparing to these people,

- obtaining information directly from other people (others' opinions about myself),

- $\quad$ social categorizations associated with belonging to particular social groups (categories) - e.g., family, school, peer group, region, nation, Europe, or the world,

- $\quad$ an insight into one’s own personality.

\section{SENSITIZATION TO THE OTHER AND NOTICING UNLIKENESS OF PEOPLE FROM OTHER CULTURES - TOWARDS THE MODIFICATION OF ETHNIC STEREOTYPES AND PREJUDICE}

As Henryk Pietrzak notices, stereotyping, most frequently experienced by children in interpersonal and group relations, concerns both individuals and groups or the whole societies, but it starts and ends with the individual's own experience. "It is the individual's consciousness where generalizations and attributions appear as a result of specific cognitive processes. Evaluating their meaning, the role of perception as the leading process (constituting the base for informative and consciousness-related transformations of other kinds) is usually highlighted" (Pietrzak, 2000, p. 105). The perception of the social world comprises already acquired knowledge of co-occurring different human qualities and the knowledge of different types of people and their typical behaviour patterns (which results in an individual way of perceiving Others). This process also involves stereotypes and prejudices, which function among individual and their negative attitude to others, including ethnic groups and nations. The results of the studies carried out in this problem area confirm the occurrence of all kinds of stereotypes and prejudices at all age levels of children from 7 to 13 years. The analysis of empirical data concerning Polish learners allow for stating that they have a well-crystallized and rather strongly negative attitude to most national minorities in Poland and that the applied attitudes of unwillingness towards others maintain for a long time, contrary to their peers from Western Europe.

Referring to Barbara Weigl's experimental studies on the modification of stereotypes and prejudices of early school learners in Opole enables to confirm both children's evident proneness to influences which shape negative attitudes to 
alien ethnic groups or nations and their susceptibility to activities which weaken such prejudice and stereotypes (Weigl, 1999, p. 31). This creates an opportunity for undertaking educational activities aiming at "weakening” the established negative stereotypes and prejudices and their modification.

\section{INTERCULTURAL COMMUNICATION AND DIALOGUE}

"Being" in one's own culture and understanding other cultures is based on language, which, for the child, is at the same time 'a tool' for communicating with the surroundings, 'the material' for creative activity, and an object of exploration. Over the last decades, due appreciation of the pragmatic factor has drawn the researchers' attention to the analysis of the development of children's talk in the aspect of the processes of social communication. Along with the children's acquisition of speaking (of specific language codes), they acquire the requirements of the social structure in which they live. The child's experience is transformed as a result of learning, which is the effect of the child's own, seemingly random, speech acts. "In this way, social structure becomes a substrate of the child's experience, which comes into being through many different linguistic processes" (Kozielecki, 1997, p. 208). From this point of view, it should be assumed that each time the child speaks or listens to others' talk, a process occurs which strengthens social structure and forms the child's cultural identity. This phenomenon can also have the following interpretation - individuals achieve control over their social roles through the process of communication.

Children's functioning in the culturally differentiated borderland environment provides them with regular linguistic contacts with their peers - members of other communities and societies, and it quite frequently creates natural situations enhancing simultaneous participation in two cultures and two linguistic systems. Bilingualism, acquired in this way, may have the "adding” (enabling high competence in both languages) or "subtracting" character, in which the more prestigious language (of the majority or dominating culture) replaces the first language (of the minority culture) and does not let the individual achieve proper fluency in any of them (Czykwin \& Misiejuk, 2002; Korczyński, 2018).

\section{COGNITIVE CONTEXTS}

\section{MOTIVATION FOR FAMILIARIZING WITH THE WORLD AND LEARNING}

Developing individual's cognitive processes and their orientation in the environment is an important aim of education. This development is characterized by intensive motivation for familiarizing with the surrounding world of people, things and phenomena, as well as for acquiring (in the process of learning) social 
competences which determine the efficiency of the individual's functioning in social situations at school and outside it. Developmental theories, which emphasize the cultural and social context of teaching and learning, highlight the role and significance of the double social structure in which the individual participates - that is, both the relation with peers (the individual's world) and the "objective reality" - created, established and imposed by adults. The dichotomous nature of the individual's functioning in two social words also brings about the necessity to fulfill their basic needs which appear in the process of:

- symbiosis (tight teaming up and union with the nearest environment) - the need for bonds, closeness and acceptance (in relations with others), which determines the feeling of safety in the human world;

- separation (gradual emerging of I out of the symbiotic unity) - the need for identity, which enables creating the borderline I - Other people;

- $\quad$ individualization (developing the inner I autonomy) - the need for self-fulfillment, the exploration of the surroundings, and independent activity, which presents the expression of one's own I (Małkiewicz, 2002, pp. 16-17).

The distinguished needs of bonds, identity and self-fulfillment become the basic determinants of the pace, dynamics and direction of individual's cognitive activeness. This activeness allows the individual for a very close relation with the nearer and further cultural environment, which also enhances "building" the representation of one's own person (among other factors, associated with preserving one's own identity and with maintaining or increasing one's own position in the social system of meanings).

\section{CONSTRUCTING KNOWLEDGE AT SCHOOL: LEARNING THROUGH INTERCULTURAL DIALOGUE AND CONTACT}

Intercultural pedagogy necessitates a different approach to the child's acquisition of knowledge - to the transition from monologue education to dialogue education, which involves generating meanings. As Jerome S. Bruner, the author of the notion 'interpretative phrase' emphasizes, "generating meanings is linked with placing the meetings with the world in their appropriate cultural context in order to learn 'what is it about?'. Although meanings are in the mind, they have their source and references in the culture in which they are created. This cultural situating of meanings ensures their negotiating nature and immersion in communication. Whether there are 'private meanings' is not an issue here; what is important is that meanings provide a basis for cultural exchange. From this point of view, cognition and communication are, in their essence, highly interrelated, 
in fact inseparable” (Bruner, 1996, p. 3). This assumption results in changes in educational theories which concern such areas as:

- the teacher's knowledge - a significant role of personal pedagogical theories, personal reflection upon one's own practice, the focus on the alternative status of educational solutions;

- the learner's knowledge - the existence of many "possible worlds" and their interpretations, the understanding dialogue, being ready for "disobedience in thinking”, creative thinking, the school's hidden programme;

- classroom communication - the social character of learning, cooperation in group aiming at the same goal (task), the searching-creative function of speech, the significance of explorative speech (thinking aloud);

- didactic planning - spontaneous experimenting, guidelines, improvisation, and goals understood as intentions and general plans.

According to Jerome S. Bruner's concept of education, the thesis treating culture as both the basic orientation of modern pedagogy and education and as the need for cultural enhancement results in defining school as the learning culture. Its fundamental task is supporting children in learning the use of tools for generating meanings and in their adjustment to the world and in changing this world dependently on the needs. Such learning culture should also contribute to shaping learners' identity and self-esteem, as well as it should strengthen the chances for managing at school and outside it (Bruner, 1996).

\section{PROSPECTS - AN ATTEMPT AT RECAPITULATION}

The presented discussion is aimed at becoming aware of the need to promote intercultural education as a current of the modern pedagogical theory and educational practice, compliant with the current requirements and offering prospects for the desired changes in future. Intercultural education is a chance for overcoming stigmatization, the feeling of alienation, the fear of Others. It is also a chance for shaping the multidimensional (enriched) identity, in which national or religious identity constitutes an important part but does not suppress the other areas of identity, does not require rejecting the people and values not compliant with the orthodox (far from life in the multicultural world) images of the group and individual identity. What becomes a necessary value in the contemporary world is the openness of cultures, which does not mean the lack of selecting the acquired influences. Only a friendly turn towards other cultures, a really personalistic view on other societies (and at the same time on particular individuals who make up these societies) 
can lay the foundations for building a new intercultural space (Kłoskowska, 2002, p. 159). However, this cannot mean uncritical acceptance of all cultural influences. Acquiring the values of other cultures should take place through openness, supported by kind-hearted criticism with the simultaneous acceptance and emphasis on every person's unalienable right to freedom.

As the current globalization processes cannot be inhibited, this issue will not lose its topicality. What is needed to prevent a lot of conflict-rising tension resulting from these processes is an idea which will indicate the rules of conduct. It is universalism, open to all topics, questions, accusations, which can become such an idea. Universalism "should be directed towards the holistic rather than fragmentary approach. Yet, this does not mean that universalism has a hostile attitude to diversity. Such type of the whole that is appropriate for an open process of reasoning tolerates and praises individuality, differences and even contradictory views. However, above this - there must be a total unity and harmony, a fundamental set of principles, accepted by all thinkers” (Andersen, 1997, p. 96; Śliwerski, 2008, pp. 55-74).

Aiming at universalism in the new reality is not merely a whim but a necessity. It becomes a chance for a conflictless and fruitful encounter with the Other. What seems important while heading for this is not to resign from the own traditions. Being rooted in the local ethnic culture offers the possibility to accept universal values and, at the same time, it protects individuals from diluting their identity.

The theoretical suggestions and practical experiences defined as intercultural education seem to undermine the ways of reasoning and the educational activity which have been perpetuated for over a century. Understanding the chances offered by intercultural education and accepting the applied educational practices require time. They also necessitate authentic engagement of many social groups which have strong influence on shaping human attitudes. In spite of many difficulties, making use of these chances is worth a lot of effort (Lewowicki, 2015, pp. 24-33).

\section{References}

Andersen, A. (1997). Istota Uniwersalizmu. In: J.M. Dołęga, J. Kuczyński, \& A. Woźnicki (Eds.), Szkoła przeżycia cywilizacyjnego (pp. 86-96). Warszawa: Wydawnictwo Naukowe "Scholar".

Biernacka, M., Krzysztofek, K., \& Sadowski, A. (Eds.). (2012). Społeczeństwo wielokulturowe - nowe wyzwania i zagrożenia. Białystok: UwB.

Bruner, J.S. (1996). The Culture of Education. Cambridge: London Harvard University Press. Czykwin, E., \& Misiejuk, D. (2002). Dwujęzyczność i dwukulturowość w perspektywie psychopedagogicznej. Białystok: Wydawnictwo Uniwersyteckie "Trans Humana". 
Gajdzica, A., Piechaczek-Ogierman, G., \& Hruzd-Matuszczyk, A. (2014). Edukacja postrzegana z perspektywy uczniów, rodziców i nauczycieli ze szkół z polskim językiem nauczania w wybranych krajach europejskich. Cieszyn-Toruń: Wydział Etnologii i Nauk o Edukacji Uniwersytetu Śląskiego, Wydawnictwo Adam Marszałek.

Grabowska, B. (2013). Poczucie tożsamości młodzieży uczqcej się w szkołach z polskim językiem nauczania na Białorusi, Ukrainie i w Republice Czeskiej - studium porównawcze. Cieszyn - Toruń: Wydział Etnologii i Nauk o Edukacji Uniwersytetu Śląskiego, Wydawnictwo Adam Marszałek.

Grzybowski, P.P. (2009). Edukacja europejska - od wielokulturowości ku międzykulturowości (koncepcje edukacji wielokulturowej i międzykulturowej w kontekście europejskim ze szczególnym uwzględnieniem środowiska frankofońskiego). Kraków: Oficyna Wydawnicza "Impuls".

Grzybowski, P.P. (2015). Śmiech w edukacji: od szkolnej wspólnoty śmiechu po edukację międzykulturowq. Kraków: Oficyna Wydawnicza “Impuls”.

Jagoszewska, J. (1995). Jednostka ludzka i jej relacje do kultury w psychologii humanistycznej. In: S. Pietraszko (Ed.), Kultura a jednostka ludzka. Prace Kulturoznawcze V (pp. 9-23). Wrocław: UW.

Kłoskowska, A. (2002). Kultury narodowe wobec globalizacji a tożsamość jednostki. Kultura i Społeczeństwo, 2, pp. 155-173.

Kohlberg, L., \& Mayer, R. (1993). Rozwój jako cel wychowania. In: Z. Kwieciński, \& L. Witkowski (Eds.), Spory o edukację. Dylematy i kontrowersje we współczesnych pedagogiach (pp. 51-95). Warszawa: IBE.

Konopczyński, M., Theiss, W., \& Winiarski, M. (Eds.). (2010). Pedagogika społeczna. Przestrzenie życia i edukacji. Księga pamiątkowa dedykowana Profesorowi Tadeuszowi Pilchowi. Warszawa: PEDAGOGIUM Wyższa Szkoła Pedagogiki Resocjalizacyjnej.

Korczyński, M. (2017). Rola inteligencji emocjonalnej jako kompetencji międzykulturowej w osiągnięciu sukcesu zawodowego polskich emigrantów. Edukacja Międzykulturowa, 2(7), pp. 185-199.

Korczyński M. (2018). Kompetencje międzykulturowe a wykształcenie polskich emigrantów w Anglii. Journal of Modern Science, 36 (1), pp. 93-112. DOI: 10.13166/jms/85333.

Korporowicz, L. (2011). Socjologia kulturowa: kontynuacje i poszukiwania. Kraków: UJ.

Kozielecki, J. (1997). Transgresja i kultura. Warszawa: Wydawnictwo Akademickie “Żak”.

Kurzępa, J. (2007). Socjopatologia pogranicza. Zmiany w życiu społeczności zachodniego pogranicza. Studium socjologiczne. Zielona Góra: UZ.

Kyuchukov, H., Lewowicki, T., \& Ogrodzka-Mazur, E. (Eds.). (2015). Intercultural Education: Concepts, Practice, Problems. Munich: LINCOM Academic Publishers.

Lewowicki, T. (1995). Problemy tożsamości narodowej - w poszukiwaniu sposobów uogólnionych ujęć kwestii poczucia tożsamości i zachowań z tym poczuciem związanych. In: J. Nikitorowicz (Ed.), O badaniach społeczności pogranicza - od parcjalnych opisów ku elementom teorii zachowań tożsamościowych (pp. 13-26). Białystok: Wydawnictwo Uniwersyteckie “Trans Humana”.

Lewowicki, T. (2006). Edukacja międzykulturowa - konteksty polityczne i ideologiczne, idee pedagogiczne, doświadczenia społeczne i praktyka edukacyjna (zderzenia deklaracji i działań - czas próby?). In: T. Lewowicki, \& E. Ogrodzka-Mazur (Eds.), Z teorii i prak- 
tyki edukacji międzykulturowej (pp. 261-270). Cieszyn: UŚ, Wyższa Szkoła Pedagogiczna ZNP w Warszawie.

Lewowicki, T. (2010). Socjologizm vs. pedagogizm - czy synteza w edukacji międzykulturowej? In: T. Lewowicki, \& E. Ogrodzka-Mazur (Eds.), Edukacja międzykulturowa - teorie, poglądy, doświadczenia społeczne (pp. 303-309). Cieszyn-Warszawa-Toruń: Wydział Etnologii i Nauk o Edukacji Uniwersytetu Śląskiego, Wyższa Szkoła Pedagogiczna ZNP w Warszawie, Wydawnictwo Adam Marszałek.

Lewowicki, T. (2011). O doświadczeniach edukacji wielokulturowej oraz perspektywie edukacji i pedagogiki międzykulturowej. In: T. Lewowicki, E. Ogrodzka-Mazur, \& A. Szczurek-Boruta (Eds.), Edukacja międzykulturowa - dokonania, problemy, perspektywy (pp. 479-503). Cieszyn - Warszawa - Toruń: Wydział Etnologii i Nauk o Edukacji Uniwersytetu Śląskiego, Wyższa Szkoła Pedagogiczna ZNP w Warszawie, Wydawnictwo Adam Marszałek,

Lewowicki, T. (2012). Edukacja międzykulturowa - bilans otwarcia. Edukacja Międzykulturowa, 1 , pp. 15-46.

Lewowicki, T. (2013). Edukacja wobec odwiecznych i współczesnych problemów świata - konteksty i wyzwania edukacji międzykulturowej. Edukacja Międzykulturowa, 2, pp. 19-37.

Lewowicki, T. (2015). Intercultural Education - From Assimilation to Integration and Multidimensional Identity. In: H. Kyuchukov, T. Lewowicki, \& E. Ogrodzka-Mazur (Eds.), Intercultural Education: Concepts, Practice, Problems (pp. 24-33). Munich: LINCOM Academic Publishers.

Lewowicki, T. (2017). Edukacja międzykulturowa - kilka lat później. Zmiana uwarunkowań, pytania o kondycję, wyzwania. Edukacja Międzykulturowa, 2, pp. 19-36.

Lewowicki, T., Ogrodzka-Mazur, E., \& Szczurek-Boruta, A. (Eds.). (2000). Edukacja międzykulturowa w Polsce i na świecie. Katowice: UŚ.

Lewowicki, T., \& Suchodolska, J. (Eds.). (2011). Dzieci w procesie kształtowania postaw kulturowych. Przewodnik po ścieżkach edukacji regionalnej, wielo- i międzykulturowej. Materiały dla nauczycieli przedszkoli i szkół podstawowych. Katowice-Cieszyn-Warszawa-Kraków: Wydział Etnologii i Nauk o Edukacji Uniwersytetu Śląskiego, Wyższa Szkoła Pedagogiczna ZNP w Warszawie, Oficyna Wydawnicza “Impuls”.

Łazarewicz, M., Winiarska, A., Łączyńska, M., \& Dziechciarz, M. (Eds.). (2016). A Practical Guide to Cultural Adaptation, Integration and Psychosocial Support for International Students. Warszawa: Medical University of Warsaw.

Małkiewicz, E. (2002). Motywy poznawania świata i uczenia się w kontekście podstawowych potrzeb dziecka. In: M. Kochan-Wójcik, A. Krajna, Z. Kuklińska, \& E. Małkiewicz (Eds.), Edukacja elementarna a diagnoza pedagogiczna (pp. 16-20). Warszawa: CODN.

Misiejuk, D. (2013). Dziedzictwo i dziedziczenie w kontekście procesów socjalizacji. Studium teoretyczno-empiryczne o procesach dziedziczenia kulturowego na historycznym pograniczu Podlasia. Białystok: Wydawnictwo Uniwersyteckie “Trans Humana”.

Młynarczuk-Sokołowska, A. (2016). Od obcości do inności. Międzykulturowa edukacja nieformalna na przykładzie działań polskich organizacji pozarzq̨dowych. Warszawa: Wydawnictwo Akademickie “Żak".

Muszyńska, J. (2014). Miejsce i wspólnota: poczucie wspólnotowości mieszkańców północnowschodniego pogranicza Polski. Studium pedagogiczne. Warszawa: Wydawnictwo Akademickie “Żak”. 
Nikitorowicz, J. (1995). Pogranicze - Tożsamość - Edukacja międzykulturowa. Białystok: Wydawnictwo Uniwersyteckie “Trans Humana”.

Nikitorowicz, J. (2005). Kreowanie tożsamości dziecka. Wyzwania edukacji międzykulturowej. Gdańsk: GWP.

Nikitorowicz, J. (2009). Edukacja regionalna i międzykulturowa. Warszawa: WAiP.

Nikitorowicz, J. (2017). Etnopedagogika w kontekście wielokulturowości i ustawicznie kształtującej się tożsamości. Kraków: Oficyna Wydawnicza "Impuls”.

Ogrodzka-Mazur, E. (2007). Kompetencja aksjologiczna dzieci w młodszym wieku szkolnym. Studium porównawcze środowisk zróżnicowanych kulturowo. Katowice: UŚ.

Ogrodzka-Mazur, E. (2013). Intercultural Education in Schools of the Polish-Czech Borderland: Experiences - Problems - Prospects. The New Educational Review, 34(4), pp. 99-110.

Ogrodzka-Mazur, E., Klajmon-Lech, U., \& Różańska, A. (2014). Tożsamość kulturowa, religijność i edukacja religijna postrzegana z perspektywy społeczności szkół z polskim językiem nauczania w wybranych krajach europejskich. Cieszyn-Toruń: Wydział Etnologii i Nauk o Edukacji Uniwersytetu Śląskiego, Wydawnictwo Adam Marszałek.

Ogrodzka-Mazur, E., Grabowska, B., Szafrańska-Gajdzica, A., \& Kwadrans, Ł. (2016). Education of Children and Youth in Culturally Diverse Environments: Experience - Problems - Prospects. Munich: LINCOM Academic Publishers.

Ostrowicka, H. (2013). Dyskurs pedagogiczny jako element urządzania młodzieży. Teraźniejszość - Człowiek - Edukacja, 2, pp. 49-73.

Pietrzak, H. (2000). Następstwa i efekty stereotypowego postrzegania człowieka i świata społecznego. Rzeszów: WSP.

Różańska, A. (2015). Edukacja religijna młodzieży w warunkach pluralizmu religijnego w wybranych krajach Europy Środkowo-Wschodniej (Grupa Wyszehradzka: Polska, Czechy, Słowacja, Węgry) - studium porównawcze. Cieszyn-Toruń: Wydział Etnologii i Nauk o Edukacji Uniwersytetu Śląskiego, Wydawnictwo Adam Marszałek.

Sobecki, M. (2007). Kultura symboliczna a tożsamość. Studium tożsamości kulturowej Polaków na Grodzieńszczyźnie z perspektywy edukacji międzykulturowej. Białystok: Wydawnictwo Uniwersyteckie “Trans Humana”.

Sobecki, M. (2016). Komunikacja międzykulturowa w perspektywie pedagogicznej. Studium z pogranicza polsko-litewsko-białorusko-ukraińskiego. Warszawa: Wydawnictwo Akademickie "Żak".

Syrek, E. (Ed.). (2010). Czas społeczny akademickiego uczestnictwa w rozwoju i doskonaleniu civil society. Księga jubileuszowa dedykowana Profesorowi Andrzejowi RadziewiczowiWinnickiemu w 65. rocznicę urodzin. Katowice: UŚ.

Szczurek-Boruta, A. (2013). Doświadczenia społeczne w przygotowaniu przyszłych nauczycieli do pracy w warunkach wielokulturowości. Cieszyn-Toruń: Wydział Etnologii i Nauk o Edukacji Uniwersytetu Śląskiego, Wydawnictwo Adam Marszałek.

Sztompka, P. (2012). Socjologia. Analiza społeczeństwa. Kraków: Społeczny Instytut Wydawniczy Znak.

Sztompka, P. (2016). Kapitał społeczny: teoria przestrzeni międzyludzkiej. Kraków: Społeczny Instytut Wydawniczy Znak.

Śliwerski, B. (2008). Uniwersalizm jako metanarracja alternatywnego myślenia w/o edukacji (na przykładzie wybranych współczesnych koncepcji pedagogicznych). In: E. Dubas, 
H.M. Griese, \& M. Dzięgielewska (Eds.), Uniwersalia w międzykulturowym porównaniu. Studium polsko-niemieckie (pp. 55-74). Łódź: UŁ.

Urban, J. (2014). Mniejszości narodowe krajów Grupy Wyszehradzkiej w procesach integracyjnych Europy - tożsamość młodzieży mniejszości autochtonicznych. Cieszyn-Toruń: Wydział Etnologii i Nauk o Edukacji Uniwersytetu Śląskiego, Wydawnictwo Adam Marszałek.

Urlińska, M.M., \& Jurzysta K. (2016). Pomiędzy nadziejq a (nie)spełnieniem. Rola polskiego nauczyciela na Łotwie. Toruń: UMK.

Weigl, B. (1999). Stereotypy i uprzedzenia etniczne u dzieci i młodzieży. Studium empiryczne. Warszawa: IP PAN.

Wojakowski, D. (2007). Swojskość i obcość w zmieniajq̨cej się Polsce. Warszawa: IFiS PAN.

Wojnar, I. (1996). Aktualne problemy edukacji i kultury w Polsce i na świecie. In: I. Wojnar, \& J. Kubin (Eds.), Edukacja wobec wyzwań XXI wieku (pp. 15-34). Warszawa: Komitet Prognoz "Polska w XXI wieku” przy Prezydium PAN. 